\title{
Leverage and Corporate Market Value: Empirical Evidence from Zimbabwe Stock Exchange
}

\author{
Trevor Jambawo ${ }^{1}$ \\ ${ }^{1}$ Department of Accounting, Finance and Economics, University of Westminster, United Kingdom \\ Correspondence: Trevor Jambawo, Department of Accounting, Finance and Economics, University of \\ Westminster, United Kingdom. 62 Ceres Road, London, SE18 1HL, United Kingdom. E-mail: \\ trevorjambawo@gmail.com
}

Received: January 22, 2014

Accepted: February 5, 2014

Online Published: March 25, 2014

doi:10.5539/ijef.v6n4p185

URL: http://dx.doi.org/10.5539/ijef.v6n4p185

\begin{abstract}
The main objective of this paper is to investigate the effects of leverage on the Zimbabwe Stock Exchange (ZSE) listed non-financial companies for the period 2009-2012. The study empirically examined the effect of a firm's leverage along other risk factors namely dividend yield and size on its market value. The results show a positive relationship between a firm's market value and its long-term debt to equity choice. On the other hand, we find an inverse relationship between a firm's market value and its total debt to total capital ratio. Dividend yield and size are positively related with market value. In addition, an industry analysis and an examination of how the Zimbabwean corporate sector finances its growth were undertaken. We find evidence that capital structures and dividend policies vary across industries, and that firms rely much more on external finance than on internal finance.
\end{abstract}

Keywords: Zimbabwe, non-financial firms, leverage, market value, corporate financing

\section{Introduction}

\subsection{Background}

Modigliani and Miller (1958) showed that capital structure and dividend policy decisions do not affect corporate value under certain assumptions. Their propositions, also known as the irrelevance theory, purported that it is not possible to achieve optimal leverage ratio or dividend pay-out ratio. Modigliani and Miller (1963) amended previous propositions by relaxing their assumptions on corporate taxes. As a result, the authors came up with the relevance theory and showed evidence of a positive relationship between firm value and leverage.

The Modigliani and Miller (MM) propositions are an important fundamental principle to corporate leverage and dividend policy. Three main theories of capital structure namely static trade-off, pecking order and agency theories have since been proposed to explain the variation in debt ratios across companies. Theories suggest that firms consider the costs and benefits when choosing between equity and debt finance. Generally, firms choose an optimal leverage ratio that factors the benefits of debt such as interest tax shields and agency benefits (Titman \& Wessels, 1988; Korteweg, 2010).

\subsection{Objective}

The principal objective of this study is to ascertain the impact of capital structure on market value for non-financial firms in Zimbabwe, a developing country in Southern Africa. Apart from South Africa, Zimbabwe is one of the most influential countries in the region with a well-diversified economy and, a mature and active stock exchange (Mangena \& Taringana, 2007). In particular, we use leverage as the risky proxy for the analysis. This paper investigates whether it is possible to increase shareholders' wealth through leverage. In other words, is debt financing optimal and relevant to corporate value. We also consider dividend yield and size in order to enhance the robustness of our tests. Collins et al. (2012) examined the effect of a firm's capital structure on its market value for non-financial firms in Nigeria, a developing country in Western Africa. We extend the research efforts by examining non-financial firms in Zimbabwe.

Furthermore, we look at the financing practices of Zimbabwean firms and establish their sources of finance. Firms finance themselves through retained earnings and selling securities in the market namely debt and equity. A significant amount of studies has previously investigated the sources of corporate financing in the developing 
countries (see Atkin \& Glen, 1992; Singh \& Hamid, 1992; Singh, 1995; Cobham \& Subramaniam, 1998; Booth et al., 2001; Mutenheri \& Green, 2002).

The entire subsequent development of corporate finance literature is centred on Modigliani and Miller by relaxing their assumptions. Similarly, we use MM propositions as a benchmark for our analysis. The MM empirical evidence was conducted on oil and utilities sectors (Muradoglu \& Sivaprasad, 2012). We broaden our research by examining a dataset with diverse sectors (see Appendix I). The sectors will subsequently be allocated into their appropriate industries in order to determine the impact of industry gearing on market value.

\subsection{Structure}

The rest of this paper is organized in the following manner. The second part reviews the literature on capital structure. The third part explains the data and presents the methodology and empirical model adopted for the research. The forth part examines the Zimbabwean corporate financial structure and the empirical findings obtained from the multiple regression estimation. The fifth part concludes the paper.

\section{Literature Review}

\subsection{Sources of Finance}

According to Muradoglu and Whittington (2001), one of the most complex decisions facing a firm is whether to finance new investments by borrowing money or issuing more shares or with retained earnings. Atkin and Glen (1992) urged that there are a number of influences on that decision essentially firm-specific factors and country-specific factors. Several firm-specific factors like tangibility, firm size, risk, growth, market to book, stock market performance and profitability play an important role in determining a firm's capital structure. On the other hand, country-specific factors such as creditor (shareholder) right protection, gross domestic product (GDP) growth rate, corruption, law, inflation, bond (stock) market development, market (bank) based financial system play an important role in determining a firm's capital structure. Objectives of the firms may also differ. Firms in developing countries are likely to have the same objectives of growth as firms in developed countries but the choice of financing instruments may differ greatly (Alves \& Ferreira, 2011; De Jong et al., 2008; Huang $\&$ Song, 2006).

Singh and Hamid (1992) and Atkin and Glen (1992) examined the financing patterns of Zimbabwean firms in the 1980's and established internal finance to be more important than external finance. In essence, Atkin and Glen (1992) found Pakistan and Zimbabwe having the highest internal financing ratios among the developing countries. In contrast, Mutenheri and Green (2002) found that Zimbabwean companies relied more heavily on external finance for the period 1990-1999. On the whole sample of developing countries, Singh and Hamid (1992) and Atkin and Glen (1992) discovered that firms in developing countries made more use of external financing, particularly equities, to finance their growth. Yartey (2006) also discovered that Ghanaian firms finance a large proportion of their growth from external sources rather than from internal finance. Hence, Mutenheri and Green (2002) results on Zimbabwe corresponds with prior results on other developing countries that external finance was more important than internal finance.

In comparison, the results are different to the financing pattern of firms in developed countries. Corbett and Jenkinson (1996) examined corporate capital structures in Germany, U.K., U.S. and Japan for the period 19701989 and discovered internal funds to be the main source of finance in all countries. They found the U.K. and U.S. reliance on internal finance to be very striking at 93 and 96 percent respectively. Atkin and Glen (1992) examined the G7 countries for the period 1980-1988 and reported identical results. In developed markets, external finance is more important for small firms with growth opportunities than it is for large firms. Myers (1990) compared the industry financing in 8 developed countries and observed that internal finance was the main source of funding. Beck et al. (2002) disclosed that firms in most countries, including developed countries, mostly use internal finance. Firms in a few developing countries such as Colombia, Malaysia and Poland use external finance more than firms in the U.S. where financial and legal development is one of the highest.

\subsection{Leverage and Corporate Performance}

We first review studies that have been done on firms in the U.K. Muradoglu and Sivaprasad (2012) examined the relationship between capital structure and abnormal returns and concluded that abnormal returns decline in firm gearing whilst abnormal returns increase as the average industry gearing increases. Strong and Xu (1997) found average returns to be positively related to market risk, book to market equity, market leverage and negatively related to market value and book leverage. Chelley-Steley and Steeley (2005) discovered a negative relationship between stock returns and volatility. Muradoglu and Whittington (2001) showed that companies with lower leverage enjoyed considerably higher returns. They argued that low leveraged firms have an opportunity to 
increase leverage and generally carry lower financial risk. Similarly, Muradoglu et al. (2005) found companies with low leveraged ratios outperforming the market.

Masulis (1983) estimated the impact of change in debt level on firm values for a U.S. sample and deduced that both stock prices and firm values are positively related to changes in leverage. Bhandari (1988) also estimated a U.S. sample and found expected returns on common stocks to be positively related to leverage. Korteweg (2010) demonstrated that an optimal capital structure exist by showing net benefits to be increasing in leverage for low leveraged firms although they would decrease as leverage got higher. Collins et al. (2012) found stock prices to be positively related to leverage in Nigeria. The evidence from these papers is consistent with the theory that changes in the composition of debt consequently change a firm's value.

Contrary to the positive relations, some of the studies have found inverse relations between leverage and firm performance. Aivazian et al. (2005) gathered that leverage is negatively related to the level of investment in Canada. According to George and Hwang (2009), low leveraged firms have low distress probabilities and greater exposures to market risk than high leveraged firms in the U.S. This signifies that expected returns are negatively related to leverage and the probability of distress. Dimitrov and Jain (2008) found firms which increase (decrease) leverage having negative (positive) current and future stock returns in the U.S. In a related study, Cai and Zhang (2011) found a negative relationship between the leverage and stock prices in the U.S.

Smith (2012) tested the trade-off theory that debt usage creates value because of the tax deductibility of interest expense. The author examined tax-exempt institutions since they do not pay income taxes and found debt use to be positively related to the institution's size and negatively related to the institution's age, governance structure, liquidity and profitability. Hamanda (1972) tested the relationship between portfolio and corporate finance through the effect of firm's leverage. The author's findings are in line with the MM theory that there exists a positive relationship between systematic risk of a firm's stock and its leverage. Using the same analytical approach, Bowman (1979) showed that there is a theoretical relationship between systematic risk and a firm's leverage. It is important for firms to evaluate their risk exposure when making corporate financial decisions.

Financial economics has made significant literature in explaining how firms finance growth. As demonstrated by several studies, internal funds appear to be the first preference followed by debt and then equity finance in most developed countries thus supporting the pecking order theory. In the case of developing countries, considerable literature suggests firms make significant use of external finance, particularly equities, than they do with internal funds. As reflected in the literature, the relation between leverage and firm performance, particularly stock performance, has mixed empirical success. In this paper, we contribute to the literature by providing aspects of the financing decisions in Zimbabwe and examining the effect of leverage on corporate market value. Previous studies have been mostly restricted to firms in developed and emerging countries.

\section{Data and Methodology}

\subsection{Data and Selection}

In this study, we estimate the impact of leverage on the stocks listed on the ZSE using a multiple regression estimator framework. The explanatory power of other risk factors namely dividend yield and size are also examined. The ZSE is the second largest and most active stock exchange, after the Johannesburg Stock Exchange (JSE) in Southern Africa. Share prices and related data were obtained from Bloomberg. The research covers the period 2009-2012. The research period was determined based on data availability. Most of the data prior to 2009 was not available. Zimbabwe experienced hyperinflation during the period 2007-2009 which was one of the worst economic turmoil in history. The adverse economic conditions affected the financial behaviour of listed companies. There were encouraging signs of economic recovery soon after dollarizing the economy in February 2009. The Zimbabwe dollar was replaced by a multicurrency regime with the U.S. dollar as the principal currency (Mangena \& Taringana, 2007; Koech, 2011).

A sample of 71 companies listed on the ZSE as at 17 June 2013 formed the initial selection. A total of 13 financial companies constituting of banks and insurance companies were discarded as their leverage ratios exhibit different interpretations. A further sample of 34 companies was discarded because the companies did not have matching relevant data available for all the subsequent years. A final sample of 24 non-financial companies listed on the ZSE is analysed in this study.

\subsection{Variables}

The share prices are the dependent variable and leverage, dividend yield and size are the independent variables. Share prices of firms listed on the ZSE are denoted in U.S. dollars and company's closing prices are used in this study. There are many different ways leverage has been defined in literature. In this study, we use two measures 
of leverage. The first measure is defined as total debt to total capital ratio. The second measure is defined as long-term debt to total equity ratio. Earlier studies focused more on long-term debt. The total debt to total capital ratio allows us to also take into account short-term debt because we observed that it is considerably used in Zimbabwe. Collins et al. (2012) used identical measures of leverage.

We use dividend yield following Bowman (1979) who used dividend payout ratio in his research. Dividend yield shows how much a company pays out in dividends each year relative to its share price. A company's total assets are used to represent the company size. For our regression analysis, we take the natural logarithm of total assets to represent the size of firms as employed by Gul and Tsu (1998). Market capitalisation and sales are also frequently used as measures of size. For instance, Titman and Wessels (1988) used the natural logarithm of sales whereas Fama and French (1993) used natural logarithm of market capitalisation.

\subsection{Methodology}

The aim of this study is to determine whether a firm's market value is influenced by its leverage, dividend yield and size. The study will run a multiple regression test from a firm's and industry's perspective. The regression model used states that:

Where:

$$
M S_{i}=\beta_{0}+\beta_{1} \operatorname{LEV}(1)_{i}+\beta_{2} \operatorname{LEV}(2)_{i}+\beta_{3} D Y_{i}+\beta_{4} S_{S I Z E_{i}}+\varepsilon_{i}
$$

$M S_{i}=$ Market price per share in US\$ (being the dependent variable);

$\operatorname{LEV}(1)_{i}=$ Total debt/Total capital;

$\operatorname{LEV}(2)_{i}=$ Long-term debt/equity;

$D Y_{i}=$ Dividend per share/Price per share;

$S I Z E_{i}=$ Natural logarithm of total assets;

$\beta_{0}=$ Constant of the equation;

$\beta_{1}, \beta_{2}, \beta_{3}, \beta_{4}$, = Coefficients of the explanatory variables;

$\varepsilon_{i}=$ Error term.

The entire data is grouped into four industries namely Basic Materials, Consumer goods, Consumer Services and Industries (see Appendix I). The coefficients of the explanatory variables $\beta_{1}, \beta_{2}, \beta_{3}$ and $\beta_{4}$ will reveal the effect the explanatory variables have on the stock prices. A positive coefficient means an increase in the explanatory variable results in an increase in the dependent variable. In contrast, a negative coefficient means an increase in the explanatory variable results in a decrease in the dependent variable. The study will use 5 percent level of significance for the regression test.

\subsection{Descriptive Analysis}

Empirical analysis always starts with an investigation of the variables' properties. Descriptive analysis gives a unique understanding of the variables in the data set. In this section, we examine the descriptive statistics for both the dependent and explanatory variables by obtaining their mean, median, maximum, minimum, standard deviation, skewness and kurtosis values.

Table 1. Descriptive analysis

\begin{tabular}{llllll}
\hline & $M S$ & $L E V(1)$ & $L E V(2)$ & $D Y$ & SIZE \\
\hline Mean & 0.3045 & 24.5866 & 20.4147 & 0.4141 & 4.0521 \\
Median & 0.0775 & 19.1800 & 1.1550 & 0.0000 & 3.8952 \\
Maximum & 3.6000 & 80.1500 & 308.2800 & 5.5900 & 6.7747 \\
Minimum & 0.0030 & 0.4000 & 0.0000 & 0.0000 & 2.2061 \\
Std. Dev & 0.5786 & 21.2686 & 58.1937 & 1.1755 & 1.1426 \\
Skewness & 3.4652 & 1.0899 & 3.8464 & 3.0897 & 0.4173 \\
Kurtosis & 16.6725 & 3.3490 & 17.4362 & 12.1767 & 2.4710 \\
Jarque-Bera & 939.86 & 19.49 & 1070.34 & 448.79 & 3.9055 \\
\hline
\end{tabular}

Overall, the descriptive statistics in Table 1 indicate that the variables are not normally distributed but instead exhibit right tailed distributions except the transformed variable SIZE. The Jarque-Bera values for $M S, L E V$ (2) 
and $D Y$ are considerably high indicating further that the variables are not normally distributed. Most of the variables are skewed and have substantive kurtosis values. The dispersion of $L E V(2)$, measured by the standard deviation is outstandingly high at 58.2 showing that the long-term debt to equity ratio covers a broad spectrum although the mean value is significantly lower than the maximum value.

The $M S$ variable shows that, on average, most non-financial firms have relatively low share prices. The maximum share price is mere US\$3.60 whilst the average is US\$0.30. The mean value of $L E V$ (2) substantiates that, on average, the long-term debt to equity ratios of most of the firms are skewed towards equity than debt. The mean value of $L E V$ (1) also reveals that the average total debt to total capital ratio is reasonably lower. Therefore, majority of non-financial firms in Zimbabwe are not highly leveraged. Nonetheless, the highest geared firm has a staggering long-term debt to equity ratio of 308 percent. From the median, mean and minimum values of $D Y$ variable, we can deduce that firms in Zimbabwe rarely paid dividends during the sample period. Comparing our average dividend yield with the one presented by Atkin and Glen (1992) who studied Zimbabwean firms from the 1980 's, we conclude that firms barely paid dividends as a result of distress due to the economic crisis the country experienced during the period 2007-2009.

\subsection{Correlation Analysis}

A correlation matrix was performed in an effort to understand the relationship between variables. The method can determine whether a relationship exists between variables although it does not demonstrate cause and effect. The correlation coefficient provides an estimate of how related two variables are.

Table 2. Correlation analysis

\begin{tabular}{llllll}
\hline & $M S$ & LEV (1) & LEV (2) & DY & SIZE \\
\hline$M S$ & 1.000000 & & & & \\
LEV (1) & 0.240483 & 1.000000 & & & \\
LEV (2) & 0.694170 & 0.662158 & 1.000000 & & \\
$D Y$ & 0.813094 & 0.309376 & 0.705350 & 1.000000 & \\
SIZE & 0.637121 & 0.094374 & 0.364479 & 0.574067 & 1.000000 \\
\hline
\end{tabular}

An examination of the correlation matrix presented in Table 2 reveals that the most correlated variable with $M S$ variable is $D Y$. MS variable is more correlated with $L E V$ (2) variable than it is with $L E V$ (1) variable. Correspondingly, $D Y$ variable is more correlated with $L E V(2)$ variable than it is with $L E V(1)$ variable. The most correlated variables are $M S$ and $D Y$ variables with a correlation coefficient of 0.81 . Overall, there is no strong evidence of multicollinearity. Even so, Niguez (2012) urged that the presence of multicollinearity does not mean that the model is misspecified. The regression coefficients remain unbiased and standard errors remain valid although larger than they would be in absence of multicollinearity. Further test will be conducted using the Durbin-Watson test in the section 4.2.

Based on the correlation matrix, we exclusively conclude that firms with higher levels of long-term debt to equity ratio are likely to pay higher dividends. The long-term debt to equity ratio has a higher positive influence on the firms' market value than the total debt to total capital ratio.

\section{Empirical Results}

\subsection{Corporate Financial Structure}

Out of the non-financial firms analysed in this study, 33 percent had long-term debt in their capital structure for the four consecutive years of research period whereas 100 percent had short-term debt in their capital structure. The total debt for all the firms rose by 53 percent from US\$576.7 million in 2009 to US\$879.7 million in 2012. Equity finance rose by 31 percent from US\$1.052 billion in 2009 to US\$1.377 billion in 2012. The figures reveal the significance of equity finance in the Zimbabwean corporate structure and how debt finance played an important role soon after the hyperinflation period. The accrual of debt and equity shows that firms required financing the revival of operations after years of dilapidation. 
Table 3. Zimbabwean corporate structure

\begin{tabular}{|c|c|c|c|c|c|}
\hline & & Internal Finance & External Finance & & \\
\hline & Period & Retained earnings & Equity & Long-term debt & Total debt \\
\hline 1 & $1980-1990$ & 58.0 & 38.8 & 3.2 & - \\
\hline 2 & $1980-1988$ & 58.5 & 43.0 & 0.0 & - \\
\hline 3 & 1990-1999 & 24.60 & 7.80 & - & 67.60 \\
\hline 4 & 2009-2012 & 34.03 & 47.98 & - & 17.99 \\
\hline
\end{tabular}

Note: 1. Singh (1995). 2. Atkin and Glen (1992). 3. Mutenheri and Green (2002). 4. Author's results.

This study uses a methodology that is different from Singh (1995) and Atkin and Glen (1992) in that it uses total debt as a measure of external finance instead of long-term debt after observing that the capital structure of firms in Zimbabwe and developing countries in general constitute mostly of short-term debt. For our results labelled 4, all figures are mean values expressed as percentage. For each firm the sum of internal and external financing sources is 100 percent. The results report the mean for each category, which sum to 100. Similarly, Singh (1995) also used mean values unlike Atkin and Glen (1992) who used median values which do not sum to 100 .

The key results of this study, as shown in Table 3, are in line with earlier results by Mutenheri and Green (2002) who found Zimbabwean corporate sector to rely more on external finance than on internal finance although our proportion of internal finance is slightly higher. We find equity finance to be the most important source of external finance which is however contrary to the results by Mutenheri and Green (2002) who found debt to be the most important source of external finance. We attribute the dissimilarities to the different time periods studied. Singh (1995) and Atkin and Glen (1992) studies covers the early Zimbabwe post-independence period when firms were mostly self-reliant whilst Mutenheri and Green (2002) period was when the global outlook was generally stable and credit was fairly obtainable. This study covers the post-global financial crisis of 2007-2009 and the Zimbabwe post-hyperinflation period.

Based on our findings, we conclude that equity finance is the most important source of long-term finance in Zimbabwe compared to long-term debt. Our inference is that the economic and political uncertainties in developing countries like Zimbabwe make it difficult for lenders to provide debt over longer time horizons. Unlike most firms in advanced countries, Zimbabwean firms finance a large proportion of its growth from external finance compared to internal finance.

\subsection{Regression Analysis}

We empirically investigate whether a firm's market value is explained by its leverage, dividend yield and size. The regression results of equation (1) are presented in Table 4. The Durbin-Watson test shows a value of 1.98 which means $d=1.98 \in\left[d_{u}, 2\right]$ implying that there is no autocorrelation in the residuals. This means our $\mathrm{R}$-squared and F-statistic give us the right inference on the significance of the coefficients thus we can rely on our model. We begin with a joint significance test for the explanatory variables of the model before examining the effects of the explanatory variables on the dependent variable. According to the goodness-of-fit, 76 percent of the variations of the explanatory variables are explained by the model. According to the p-value of the test $(0.0000<0.05)$, all the variables are jointly relevant to explain stock prices.

LEV (1) has a negative coefficient and is significant as $(\mathrm{p}=0.0076<0.05)$ meaning the variable $L E V$ (1) is statistically significant to explain market share price. $L E V(2)$ has a positive coefficient and is significant as $(\mathrm{p}=0.0000<0.05)$ meaning the variable $L E V(2)$ is statistically significant to explain market share price. $D Y$ and SIZE both have positive coefficients and are statistically significant to explain market share price.

Table 4. Regression results

\begin{tabular}{lll}
\hline Variable & Coefficient & Probability \\
\hline C & -0.246258 & 0.0778 \\
LEV (1) & -0.005351 & 0.0076 \\
LEV (2) & 0.004492 & 0.0000 \\
DY & 0.192573 & 0.0000 \\
SIZE & 0.124911 & 0.0002 \\
R-squared & 0.760297 & \\
Adjusted R-squared & 0.748745 & \\
\hline
\end{tabular}




\begin{tabular}{ll}
\hline F-statistic & 65.81540 \\
Prob(F-statistic) & 0.000000 \\
Durbin-Watson stat & 1.976211 \\
\hline
\end{tabular}

We conclude that a positive relationship exists between a firm's market value and its long-term debt to equity choice. The total debt to total capital ratio should be appropriately managed as it exhibits a negative relationship on a firm's market value. A positive relationship exists between a firm's market value and its dividend yield and size.

\subsection{Results in Comparative Perspective}

We compare our empirical results with results by Collins et al. (2012) who examined the effects of leverage on the market value of non-financial firms listed on the Nigeria Stock Exchange (NSE). A positive relationship exists between Nigerian non-financial firms' market value and their long-term debt to equity choice. The authors also found that firms in Nigeria mainly use short-term debt and are generally low leveraged. Antwi et al. (2012) investigated the impact of capital structure on the value of firms listed on the Ghana Stock Exchange (GSE) and concluded that long-term debt capital impact a firm's value more than equity capital. Yartey (2006) examined the corporate financing pattern in Ghana and concluded that Ghanaian firms rely on the stock market as a long term source of finance and finance their growth mainly from short-term debt. We observe similar patterns with Zimbabwean firms.

\subsection{Industry Analysis}

The four industries of this dataset are basic materials, consumer goods, consumer services and industrials. None of the firms in the basic materials and consumer services industries paid dividends during the sample period. As a consequence, we omitted the variable dividend yield for these two industries because it was causing the regression model to be unstable. The regression results for each industry are presented in Table 5.

Table 5. Regression results

\begin{tabular}{lc}
\hline \multicolumn{1}{c}{ Variable } & Coefficient \\
\hline Basic Materials & \\
$\mathrm{C}$ & -0.579085 \\
LEV (1) & 0.001216 \\
LEV (2) & -0.000740 \\
SIZE & 0.168350 \\
Consumer goods & \\
$\mathrm{C}$ & -0.129915 \\
LEV (1) & -0.012626 \\
LEV (2) & 0.015248 \\
$D Y$ & 0.017510 \\
SIZE & 0.136821 \\
Consumer services & \\
$\mathrm{C}$ & \\
LEV (1) & -0.014161 \\
LEV (2) & 0.000681 \\
SIZE & -0.000167 \\
Industrials & 0.006562 \\
$\mathrm{C}$ & \\
LEV (1) & -0.143785 \\
LEV (2) & -0.009248 \\
$D Y$ & 0.006332 \\
SIZE & 0.154146 \\
\hline
\end{tabular}

The regression results in Table 5 indicate that total debt to total capital ratio and size are positively related with market share price for the basic materials industry. An inverse relationship exists between long-term debt to equity ratio and market share price for the basic materials industry. Long-term debt to equity ratio, dividend yield and size are positively related with market share price for the consumer goods industry. Whereas total debt to 
total capital ratio is inversely related with market share price for the consumer goods industry. This trend is similar to the results of the industrials industry and the overall sample. Total debt to total capital ratio and size are positively related with market share price for the consumer services industry. On the other hand, long-term debt to equity ratio is inversely related with market share price for the consumer services industry.

\section{Conclusion}

The results that emerge from this paper are that Zimbabwean non-financial firms are generally low leveraged as evidenced by an average total debt to total capital ratio of 24.6 percent. Short-term debt is the most accessible and utilized source of debt finance in the Zimbabwean corporate sector. After experiencing hyperinflation during the period 2007-2009, firms rarely paid dividends during the period 2009-2012 as evidenced by an average dividend yield of 0.4 percent. The results show that firms alter their dividend policies when the economy has been subject to substantial disturbances.

The results from our empirical test revealed that dividend yield and size are positively related with firms' corporate value. The corporate value increases as long-term debt increases implying that it is feasible for a firm to attain an optimal leverage ratio thus increase shareholders' wealth by managing its long-term debt to a threshold where its risk is plausible and the debt benefits are utilized. Remarkably, the results support the MM relevance theory that a firm's market value increases as debt increases. The lower cost of long-term debt can raise a firm's return on equity and increase the value of stocks. However, lenders are not keen to provide debt over longer time horizons because of the economic and political risks exhibited by countries like Zimbabwe. We observed that capital structures and dividend policies vary across industries. Consumer services industry is the most leveraged industry whereas consumer goods industry is the least leveraged industry. Firms in the basic materials and consumer services industries paid zero dividends during the sample period.

Our findings are slightly different from previous studies on Zimbabwe notably in the 1980's suggesting that sources of finance vary over time. The Zimbabwe corporate sector relies more on external finance than internal finance. This financing pattern is similar to many other developing countries. The stock market is the most important source of external and long-term finance in Zimbabwe. In addition, Zivengwa et al. (2011) discovered a positive relationship between the stock market and economic growth in Zimbabwe for the period 2003-2008. For these reasons, the government needs to review its indigenisation policy. The Zimbabwean corporate sector risks attracting investors due to the indigenisation policy aimed at providing 51 percent ownership to local indigenous Zimbabweans. It is evident from the ZSE mining index presented in Appendix II that the economic crisis experienced by the country during the period 2007-2009 had an impact on the performance of the listed stocks. The index fell to its lowest beginning of 2009 and repeatedly during the period 2012-2013. The new low in 2012 was a result of cautious trading by investors pending the uncertainties regarding the indigenisation policy in the mining sector (African Development Bank, 2012).

\section{Acknowledgements}

The author would like to thank two anonymous referees for helpful comments and the scholarship department at University of Westminster.

\section{References}

African Development Bank. (2012). Zimbabwe Monthly Economic Review. June Issue. No 7.

Aivazian, V. A., Ge, Y., \& Qui, J. (2005). The impact of leverage on firm investment: Canadian Evidence, Journal of Corporate Finance, 11(1-2), 277-291. http://dx.doi.org/10.1016/S0929-1199(03)00062-2

Alves, P. F. P., \& Ferreira, M. A. (2011). Capital structure and law around the world. Journal of Multinational Financial Management, 21, 119-150. http://dx.doi.org/10.1016/j.mulfin.2011.02.001

Antwi, S., Mills, E. F. E. A., \& Zhao, X. (2012). Capital structure and firm value: Empirical evidence from Ghana, International Journal of Business and Social Science, 3(22), 103-111.

Atkin, M., \& Glen, J. (1992). Comparing corporate capital structures around the globe. The International Executive, 34(5), 369-387. http://dx.doi.org/10.1002/tie.5060340502

Beck, T., Demirguc-Kunt, A., \& Maksimovic, V. (2002). Financing patterns around the world: The role of institutions. World Bank Policy Research Working Paper, No 2905.

Bhandari, L. C. (1988). Debt/equity ratio and expected common stock returns: Empirical evidence. Journal of Finance, 43(2), 507-528. http://dx.doi.org/10.1111/j.1540-6261.1988.tb03952.x

Booth, L., Aivazian, V., Demirguc-Kunt, A., \& Maksimovic, V. (2001). Capital structures in developing 
countries. Journal of Finance, 56(1), 87-130. http://dx.doi.org/10.1111/0022-1082.00320

Bowman, R. G. (1979). The theoretical relationship between systematic risk and financial (accounting) variables. Journal of Finance, 34(3), 617-630. http://dx.doi.org/10.1111/j.1540-6261.1979.tb02129.x

Cai, Z., \& Zhang, Z. (2011). Leverage change, debt overhang, and stock prices. Journal of Corporate Finance, 17, 319-402. http://dx.doi.org/10.1016/j.jcorpfin.2010.12.003

Chelley-Steeley, P. L., \& Steeley, J. M. (2005). The leverage effect in the U.K. stock market. Applied Financial Economics, 5, 409-423. http://dx.doi.org/10.1080/0960310052000337669

Cobham, D., \& Subramaniam, R. (1998). Corporate finance in developing countries: New evidence for India. World Development, 26(6), 1033-1047. http://dx.doi.org/10.1016/S0305-750X(98)00025-4

Collins, O. S., Filibus, I. E., \& Clement, A. A. (2012). Corporate capital structure and corporate market value: Empirical evidence from Nigeria. International Journal of Economics and Finance, 4(12), 193-201. http://dx.doi.org/10.5539/ijef.v4n12p193

Corbett, J., \& Jenkinson, T. (1996). The financing of industry, 1970-1989: An international comparison. Journal of Japanese and International Economies, 10(1), 71-96. http://dx.doi.org/10.1006/jjie.1996.0004

De Jong, A., Kabir, R., \& Nguyen, T. T. (2008). Capital structure around the world: The roles of firm- and country-specific determinants. Journal of Banking and Finance, 32(9), 1954-1969. http://dx.doi.org/10.1016/j.jbankfin.2007.12.034

Dimitrov, V., \& Jain, P. C. (2008). The value relevance of changes in financial leverage beyond growth in assets and GAAP earnings. Journal of Accounting, Auditing and Finance, 191-222. Retrieved from http://papers.ssrn.com/sol3/papers.cfm?abstract_id=708281

Fama, E. F., \& French, K. R. (1993). Common risk factors in the returns on stocks and bonds. Journal of Financial Economics, 33(1), 3-56.

George, T. J., \& Hwang, C. (2009). A resolution of the distress risk and leverage puzzles in the cross section of stock returns. Journal of Financial Economics, 96, 56-79. http://dx.doi.org/10.1016/j.jfineco.2009.11.003

Gul, F. A., \& Tsui, J. S. L. (1998). A test of the free cash flow and debt monitoring hypotheses: Evidence from audit pricing. Journal of Accounting and Economics, 24, 219-237. http://dx.doi.org/10.1016/S0165-4101(98)00006-8

Hamada, R. S. (1972). The effect of the firm's capital structure on the systematic risk of common stocks. Journal of Finance, 27(2), 435-452. http://dx.doi.org/10.1111/j.1540-6261.1972.tb00971.x

Huang, G., \& Song, F. M. (2006). The determinants of capital structure: Evidence from China. China Economic Review, 17(1), 14-36. http://dx.doi.org/10.1016/j.chieco.2005.02.007

Koech, J. (2011). Hyperinflation in Zimbabwe, federal reserve bank of Dallas. Globalization and Monetary Policy Institute Annual Report. Retrieved http://www.dallasfed.org/assets/documents/institute/annual/2011/annual11b.pdf

Korteweg, A. (2010). The net benefits to leverage. Journal of Finance, 65(6), 2137-2170. http://dx.doi.org/10.1111/j.1540-6261.2010.01612.x

Mangena, \& Taringana. (2007). Disclosure, corporate governance and foreign share ownership on the Zimbabwe stock exchange. Journal of International Financial Management and Accounting, 18(2), 53-85. http://dx.doi.org/10.1111/j.1467-646X.2007.01008.x

Masulis, R. W. (1983). The impact of capital structure change on firm value: Some estimates. Journal of Finance, 38(1), 107-126. http://dx.doi.org/10.1111/j.1540-6261.1983.tb03629.x

Modigliani, F., \& Miller, M. H. (1958). The cost of capital, corporate finance and the theory of investment. American Economic Review, 48(3), 261-297. http://www.jstor.org/stable/1809766

Modigliani, F., \& Miller, M. H. (1963). Corporate income taxes and the cost of capital: A correction. American Economic Review, 53(3), 433-443. http://www.jstor.org/stable/1809167

Muradoglu, Y. G., Bakke, M., \& Gyrid, L. K. (2005). An investment strategy based on gearing ratio. Applied Economics Letters, 12(13), 801-804. http://dx.doi.org/10.1080/13504850500365780

Muradoglu, Y. G., \& Sivaprasad, S. (2012). Capital structure and abnormal returns. International Business Review, 21(3), 328-341. http://dx.doi.org/10.1016/j.ibusrev.2011.03.007 
Muradoglu, Y. G., \& Whittington, M. (2001). Predictability of U.K. stock returns by using debt ratios. CUBS Faculty of Finance Working Paper, No 5. Retrieved from http://papers.ssrn.com/sol3/papers.cfm?abstract_id=287653

Mutenheri, E., \& Green, C. J. (2002). Financial reform and financing decisions of listed firms in Zimbabwe. Working Paper Series, Paper No 44.

Myers, C. (1990). Financial systems, corporate finance, and economic development. In G. Hubbard (Ed.), Asymmetric Information, Corporate Finance and Investment. Chicago: University of Chicago Press.

Niguez, T. (2012). 4EQM7C1 Lecture notes. Data Analysis, University of Westminster.

Singh, A. (1995). Corporate financing patterns in industrializing economies: A comparative international study. International Finance Corporation, Technical Paper No 2.

Singh, A., \& Hamid, J. (1992). Corporate financial structures in developing countries. International Finance Corporation, Technical Paper No 1.

Smith, G. P. (2012). Capital structure determinants for tax-exempt organisations: Evidence from the UK. Financial Accountability \& Management, 28(2), 0267-4424.

Strong, N., \& Xu, X. G. (1997). Explaining the cross-Section of UK expected stock returns. British Accounting Review, 29, 1-23. http://dx.doi.org/10.1006/bare.1996.0030

Titman, S., \& Wessels, R. (1988). The determinants of capital structure choice. Journal of Finance, 43(1), 1-19. http://dx.doi.org/10.1111/j.1540-6261.1988.tb02585.x

Yartey. C. A. (2006). The stock market and the financing of corporate growth in Africa: The case of Ghana. IMF Working Paper, Washington. Retrieved from http://www.imf.org/external/pubs/ft/wp/2006/wp06201.pdf

Zivengwa, T., Mashika, J., Bokosi, F. K., \& Makova, T. (2011). Stock market development and economic growth in Zimbabwe. International Journal of Economics and Finance, 3(5), 140-150. Retrieved from http://ccsenet.org/journal/index.php/ijef/article/view/12326/8635

\section{Appendix A}

Table A1. ZSE sector and industry classification

\begin{tabular}{lll}
\hline Industry & Sector & Company Name \\
\hline Basic Materials & Paper and Packaging & ART Corporation Limited \\
& Mining & Hunyani Holdings Limited \\
Consumer Goods & Beverages & Hwange Colliery Company Limited \\
& Food & African Distillers Limited \\
& Agricultural & AICO Africa Limited \\
& & Ariston Holdings Limited \\
Consumer Services & Border Timbers Limited \\
& Property & Dairibord Holdings Limited \\
& Tourism & Delta Corporation Limited \\
& Retail & African Sun Limited \\
& Transport & Dawn Properties Limited \\
& & Edgars Stores Limited \\
Industrials & Andustrial Holding & Pioneer Corporation Africa Limited \\
& Engindustrial & Rainbow Tourism Group Limited \\
& Building and Associated Industries & Astra Industries Limited \\
& CFI Holdings Limited \\
& Innscor Africa Limited \\
& Masimba Holdings Limited \\
& National Foods Holdings Limited \\
& & Phoenix Consolidated Industries Limited \\
& Powerspeed Electrical Limited \\
& & Pretoria Portland Cement Limited \\
& TA Holdings Limited \\
& & Turnall Holdings Limited \\
\hline
\end{tabular}

Source: Zimbabwe Stock Exchange; Bloomberg. 


\section{Appendix B}

Table B1. ZSE Mining index

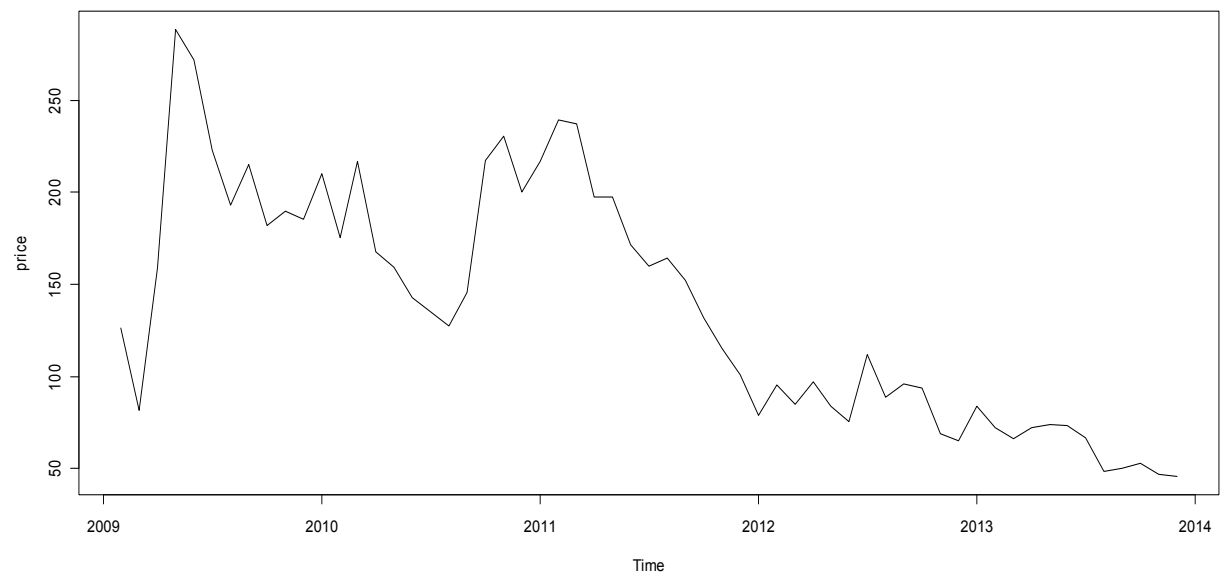

Source: Author's figure using data from Zimbabwe Stock Exchange.

\section{Copyrights}

Copyright for this article is retained by the author(s), with first publication rights granted to the journal.

This is an open-access article distributed under the terms and conditions of the Creative Commons Attribution license (http://creativecommons.org/licenses/by/3.0/). 